\title{
Synthesis of Some New Pyridine-2-yl-Benzylidene-Imines
}

\author{
Abdulhamid Alsaygh1, Jehan Al-Humaidi², Ibrahim Al-Najjar ${ }^{*}$ \\ ${ }^{1}$ Petrochemical Institute, King Abdulaziz City for Science and Technology, Riyadh, KSA \\ ${ }^{2}$ Chemistry Department, College of Science, Princess Nora Bent Abdulrahman University, Riyadh, KSA \\ Email: alnajjar@kacst.edu.sa
}

Received 9 April 2014; revised 13 May 2014; accepted 20 May 2014

Copyright @ 2014 by authors and Scientific Research Publishing Inc.

This work is licensed under the Creative Commons Attribution International License (CC BY).

http://creativecommons.org/licenses/by/4.0/

c) (i) Open Access

\begin{abstract}
A series of new Schiff bases derived from 2-aminopyridenes and various aromatic aldehydes have been synthesized and thoroughly investigated by ${ }^{1} \mathrm{H}$ and ${ }^{13} \mathrm{C}$ NMR spectroscopy. The imines were found to exist as only a single E-isomer at ambient temperature. Interestingly, ${ }^{1} \mathrm{H}-$ and ${ }^{13} \mathrm{C}$-NMR chemical shifts of the $(\mathrm{CH}=\mathrm{N})$ amino group are affected by the type of substituent group (X) on the aryl ring. Furthermore UV and IR Spectra of some of the title compounds are also reported.
\end{abstract}

\section{Keywords}

Schiff's Bases, ${ }^{1} \mathrm{H},{ }^{13} \mathrm{C}-\mathrm{NMR}$, Pyridine-2-yl-Benzylidene, E-Z-Isomers, Azomethane Group

\section{Introduction}

Schiff bases appear to be an important intermediate in a number of enzymatic reactions involving interaction of an enzyme with an amino or a carbonyl group of the substrate. One of the most important types of catalytic mechanism is the biochemical process which involves the condensation of a primary amine in an enzyme usually that of a lysine residue, with a carbonyl group of the substrate to form an imine, or Schiff base. Many studies have been carried out on various rings such as triazoles, pyrazoles, oxadiazoles, and imidazoles to develop new antibacterial agents. In view of these reports, the synthesis of a new series of substituted 2-aminopyridine derivatives is reported here since pyridine derivatives continue to attract great interest due to the wide variety of interesting biological activities observed in these compounds, such as anticancer, analgesic, antimicrobial, and antidepressant, activities [1]-[8].

*Corresponding author.

How to cite this paper: Alsaygh, A., et al. (2014) Synthesis of Some New Pyridine-2-yl-Benzylidene-Imines. International Journal of Organic Chemistry, 4, 116-121. http://dx.doi.org/10.4236/ijoc.2014.42013 


\section{Experimental}

\subsection{Materials and Methods}

2-Aaminopyridine and its substituents andbenzaldehyde and its substituents were procured from Lancaster Synthesis Ltd and were used without any further purification.

\subsection{Instruments}

IR spectra were measured using Nexus, 470-670-760 spectrophotometer FT IR, spectrometer spectrum 8400 s, using $\mathrm{KBr}$ pellets for solid compounds and neat liquid compounds between $\mathrm{KBr}$ plates. NMR spectra were measured at $24^{\circ} \mathrm{C}$ on a Jeol $400 \mathrm{MHz}$ spectrometer using deuterium locking ${ }^{13} \mathrm{C}\left({ }^{1} \mathrm{H}\right)$-NMR observation frequency $100 \mathrm{MHz},{ }^{1} \mathrm{H}-\mathrm{NMR}$,observation frequencies, $400 \mathrm{MHz}$.

\subsection{Synthesis of Schiff's Bases}

The Schiff bases were prepared by mixing equivalent amounts of substituted aryl aldehydes and 2-aminopyridine derivatives in $80 \mathrm{ml}$. methanol. This mixture was boiled under reflux with stirring for $9 \mathrm{~h}$ at $80^{\circ} \mathrm{C}$ in an oil bath, and then concentrated by rotary evaporation to give yellow liquid. This was treated with n-hexane to precipitate the crude product, which was recrystallized in dichloromethane and with n-hexane to give yellow precipitate, dried. Yield 70\% - 90\%, (Scheme 1, Table 1).

The microanalytical data and m.pts. Data are listed in Table 2, for the synthesized Schiff bases.

${ }^{1} \mathrm{H}-\mathrm{NMR}$ (400 MHz, $\mathrm{CDCl}_{3}, \delta$ ppm), compound 1, 7.31 (H-3-arom.), 7.24 (H-4, arom.), H-5 (7.81, arom., H-6 (8.49, arom.), H-3' (7.43, arom.), H-4' (7.34 arom.), H-5' (6.69, arom.), H-6' (7.58, arom.), -OH (13.48), HC=N (9.44); compound 2, H-5 (6.60, arom.), H-6 (8.04, arom.), H-2' (7.30, arom.), H-6' (6.82, arom.), -OH (12.60), HC=N (9.15); compound 3, H-5 (6.71, arom.), H-6 (8.45, arom.), H-3' (6.28, arom.), H-4' (7.93, arom.), H-5' (6.16, arom.), - $\mathrm{OH}$ (12.37), HC=CN (9.42); compound 4, H-5 (6.62, arom.), H-6 (8.54), H-2' (7.50, arom.), H-3'<smiles>[X]c1cccc(/C=N/c2cccnc2)c1</smiles>

Scheme 1. Synthesis of Schiff bases.

Table 1. Schiff bases compounds.

\begin{tabular}{|c|c|c|c|c|c|}
\hline Compound No. & $\mathrm{X}$ & $\mathrm{Y}$ & Compound No. & $\mathrm{X}$ & $\mathrm{Y}$ \\
\hline 1 & 2-OH & $\mathrm{H}$ & 8 & $4-\mathrm{NO}_{2}$ & 4-Me \\
\hline 2 & $\mathrm{H}$ & 3-Me & 9 & $4-\mathrm{Br}$ & 4-Me \\
\hline 3 & 2-OH & 3-Me & 10 & $\mathrm{H}$ & 5-Cl \\
\hline 4 & $4-\mathrm{NO}_{2}$ & 3-Me & 11 & 2-OH & 5-Cl \\
\hline 5 & $4-\mathrm{Br}$ & 3-Me & 12 & $4-\mathrm{NO}_{2}$ & 5-Cl \\
\hline 6 & $\mathrm{H}$ & 4-Me & 13 & $4-\mathrm{Br}$ & 5-Cl \\
\hline 7 & $2-\mathrm{OH}$ & 4-Me & & & \\
\hline
\end{tabular}


Table 2. Microanalytical data and M.P. data for the synthesized Schiff bases.

\begin{tabular}{|c|c|c|c|c|c|c|c|c|c|}
\hline \multirow{2}{*}{ No. } & \multirow{2}{*}{$\mathrm{X}$} & \multirow{2}{*}{ M.p. $\left({ }^{\circ} \mathrm{C}\right)$} & \multirow{2}{*}{ M.F. } & \multicolumn{3}{|c|}{ Calculated (\%) } & \multicolumn{3}{|c|}{ Found (\%) } \\
\hline & & & & $\mathrm{C}$ & $\mathrm{H}$ & $\mathrm{N}$ & $\mathrm{C}$ & $\mathrm{H}$ & $\mathrm{N}$ \\
\hline 1 & $2-\mathrm{OH}$ & 73 & $\mathrm{C}_{12} \mathrm{H}_{10} \mathrm{~N}_{2} \mathrm{O}$ & 72.71 & 5.08 & 14.13 & 72.38 & 4.98 & 14.05 \\
\hline 2 & $\mathrm{H}$ & 88 & $\mathrm{C}_{13} \mathrm{H}_{12} \mathrm{~N}_{2} \mathrm{O}$ & 79.56 & 6.16 & 14.27 & 77.98 & 6.31 & 13.64 \\
\hline 3 & $2-\mathrm{OH}$ & 110 & $\mathrm{C}_{13} \mathrm{H}_{12} \mathrm{~N}_{2} \mathrm{O}$ & 73.56 & 5.69 & 13.19 & 73.63 & 5.82 & 13.34 \\
\hline 4 & $4-\mathrm{NO}_{2}$ & 130 & $\mathrm{C}_{13} \mathrm{H}_{11} \mathrm{~N}_{3} \mathrm{O}_{2}$ & 64.72 & 5.59 & 17.41 & 64.35 & 3.91 & 16.55 \\
\hline 5 & $4-\mathrm{Br}$ & 77 & $\mathrm{C}_{13} \mathrm{H}_{11} \mathrm{Br}_{\mathrm{N} 2}$ & 57.15 & 4.02 & 10.18 & 57.43 & 4.13 & 9.81 \\
\hline 6 & $\mathrm{H}$ & 84 & $\mathrm{C}_{13} \mathrm{H}_{12} \mathrm{~N}_{2}$ & 79.56 & 6.16 & 14.27 & 78.28 & 6.31 & 17.64 \\
\hline 7 & $2-\mathrm{OH}$ & 100 & $\mathrm{C}_{13} \mathrm{H}_{12} \mathrm{~N}_{2} \mathrm{O}$ & 73.56 & 5.69 & 13.19 & 73.63 & 5.82 & 13.34 \\
\hline 8 & $4-\mathrm{NO}_{2}$ & 140 & $\mathrm{C}_{13} \mathrm{H}_{11} \mathrm{~N}_{3} \mathrm{O}_{2}$ & 64.72 & 5.59 & 17.41 & 64.35 & 3.91 & 15.55 \\
\hline 9 & $4-\mathrm{Br}$ & 98 & $\mathrm{C}_{13} \mathrm{H}_{11} \mathrm{Br}_{\mathrm{N} 2}$ & 57.15 & 4.02 & 10.18 & 57.43 & 4.13 & 12.81 \\
\hline 10 & $\mathrm{H}$ & 106 & $\mathrm{C}_{12} \mathrm{H}_{9} \mathrm{CIN}_{2}$ & 66.51 & 4.15 & 12.93 & 65.68 & 4.13 & 12.32 \\
\hline 11 & $2-\mathrm{OH}$ & 94 & $\mathrm{C}_{12} \mathrm{H}_{9} \mathrm{CIN}_{2} \mathrm{O}$ & 61.93 & 3.87 & 12.01 & 61.84 & 3.78 & 12.12 \\
\hline 12 & $4-\mathrm{NO}_{2}$ & 203 & $\mathrm{C}_{12} \mathrm{H}_{8} \mathrm{CIN}_{3} \mathrm{O}_{2}$ & 55.06 & 3.05 & 16.06 & 55.80 & 3.04 & 15.89 \\
\hline 13 & $4-\mathrm{Br}$ & 180 & $\mathrm{C}_{12} \mathrm{H}_{8} \mathrm{BrCIN}_{2}$ & 48.74 & 2.70 & 9.47 & 47.31 & 2.51 & 10.67 \\
\hline
\end{tabular}

(7.71, arom.), H-5' (7.71, arom.), H-6' (7.5, arom.), -OH (12.55), HC=N (9.25); compound 5, H-5 (6.60, arom.), H-6 (8.45), H-2' (7.50, arom.), H-3' (6.81, arom.), H-5' (6.81, arom.), H-6' (7.5, arom.), -OH (12.50), HC=N (9.25); compound 6, H-6 (8.34), H-2' (7.80, arom.), H-6' (7.00, arom.), HC=N (9.15); compound 7, H-3 (6.80, arom.), H-6 (7.67), H-2' (6.96, arom.), H-6' (6.94, arom.), -OH (13.59), HC=N (9.43); compound 8, H-3 (6.80, arom.), H-6 (8.80), H-2' (7.50, arom.), H-6' (6.33, arom.), HC=N (9.26); compound 9, H-3 (6.80, arom.), H-6 (8.35), H-2' (7.80, arom.), H-6' (7.03, arom.), HC=N (9.11); compound 10, H-3 (7.48, arom.), H-4 (7.35, arom.) H-6 (8.42), H-1' (7.93, arom.), H-6' (7.27, arom.), HC=N (9.12); compound 11, H-3 (7.51, arom.), H-4 (7.10, arom.), H-6 (8.45), H-1' (7.76, arom.), H-6'(6.95 arom.), HC=N (9.41), -OH (13.24); compound 12, H-3 (8.14, arom.), H-4 (8.12, arom.) H-6 (8.44), H-1' (8.32, arom.), H-6' (7.30, arom.), HC=N (9.26); compound 13, H-3 (7.26, arom.), H-4 (7.84, arom.) H-6 (8.42), H-1' (7.26, arom.), H-6' (7.84, arom.), HC=N (9.08); ${ }^{13} \mathrm{C}-\mathrm{NMR}$ (400 $\left.\mathrm{MHz}_{\mathrm{CDCl}}, \delta \mathrm{ppm}\right)$, compound 1, C-2 (155.20), C-3 (119.50), C-4 (138.80), C-5 (123.40), C-6 (149.20), C-1' (118.20), C-2' (161.20), C-3' (119.20), C-4' (133.40), C-5' (118.10), C-6' (132.90), C=N (163.50); compound 6, C-4 (138.00), C-1' (135.00), C-2' (129.26), C-3' (128.58), C-4' (131.69), C-5' (128.58), C-6' (129.260), -CH3 (20.97); compound 7, C-2 (156.69), C-3 (121.98), C-4 (138.37), C-5 (121.98), C-6 (157.88), C-1' (118.93), C-2' (161.62), C-3' (117.09), C-4' (133.22), C-5' (118.87), C-6' (133.45), C=N (164.15), - $\mathrm{CH}_{3}$ (24.38); compound 8, C-2 (159.16), C-3 (125.49), C-4 (137.00), C-5 (125.49), C-6 (149.20), C-1' (137.16), C-2' (129.33), C-3' (134.40), C-4' (148.05), C-5' (134.40), C-6' (129.33), C=N (159.39), - $\mathrm{CH}_{3}$ (20.93); compound 9, C-2 (148.33), C-3 (134.01), C-4 (136.56), C-5 (134.01), C-6 (149.39), C-1' (134.67), C-2' (130.57), C-3' (131.88), C-4' (120.56), C-5' (131.88), C-6' (130.87), C=N (161.13), - $\mathrm{CH}_{3}$ (20.97); compound 10, C-2 (159.39), C-3 (120.85), C-4 (137.51), C-5 (137.58), C-6 (157.07), C-1' (137.88), C-2' (129.88), C-3' (132.26), C-4' (129.66), C-5' (132.26), C-6' (128.90), C=N (163.46); compound 11, C-2 (161.59), C-3 (133.45), C-4 (137.96), C-5 (130.24), C-6 (147.57), C-1' (121.60), C-2' (155.64), C-3' (117.14), C-4' (133.99), C-5' (119.22), C-6' (133.45), C=N (164.97); compound 12, C-1 (158.47), C-2 (131.00), C-4 (138.04), C-5 (130.14), C-6 (149.85), C-1' (141.14), C-2' (130.98), C-3' (124.08), C-4' (147.85), C-5' (124.04), C-6' (130.18), C=N (160.52); compound 13, C-2 (158.95), C-3 (134.64), C-4 (137.95), C-5 (130.13), C-6 (147.41), C-1' (137.958), C-2' (132.23), C-3' (130.94), C-4' (121.09), C-5' (130.94), C-6' (132.23), C=N (162.00).

\section{Results and Discussion}

In the present work, the new 2-(X-benzylidine)-Y-pyridins (Schiff's bases) were obtained from the reaction of 
X-benzaldehydes with 2-amino-Y-pyridines. The products were solids and the yields were $70 \%-90 \%$, reasonably high which indicates greater reactivity of these carbonyl compounds.

\subsection{The Stereochemistry of the Schiff's Bases}

The stereochemistry of the free imines was determined on the basis of their ${ }^{1} \mathrm{H}$ and ${ }^{13} \mathrm{C}-\mathrm{NMR}$ spectral data. The ${ }^{1} \mathrm{H}$-NMR spectrum (in $\mathrm{CDCl}_{3}$ ), shows that there is only one set of isomer signals, exist mainly in E-imine form.

\subsection{IR, ${ }^{1} \mathrm{H}$ and ${ }^{13} \mathrm{C}-\mathrm{NMR}$ Spectra}

The infrared spectra show that the absorption of the $\mathrm{C}=\mathrm{N}$ group for imines 1 - 13 (Table 1) occurred in the region (v1590 $\left.-1620 \mathrm{~cm}^{-1}\right)$ as one band for each imine. In addition to the absorption of proton of $\left({ }^{1} \mathrm{H}-\mathrm{C}=\mathrm{N}\right)$ group, occurred in the region ( $\delta 9.01-9.43 \mathrm{ppm})$ as one single peak for each imine. Inspection of the region $700-900$ $\mathrm{cm}^{-1}$, where C-H out of plane bending vibrations of the aromatic ring is expected, did not result in the observation of mixtures of E- and Z-diastereoisomers [9].

The IR results are in good agreement with an earlier study of some imines derived from some thiophene and furfural derivatives which have been reported to exist exclusively in the E-form [10]-[12]. Further evidence of formation of imine is the absence of absorption of $\mathrm{C}=\mathrm{O}$ group at $\left(1695-1700 \mathrm{~cm}^{-1}\right)$ and absence of absorption of $\mathrm{NH}_{2}$ group at ca. $3300 \mathrm{~cm}^{-1}$ for symmetric stretching frequency and unsymmetric frequency at $3450 \mathrm{~cm}^{-1}$. In addition, further evidence comes from the absorption of $\mathrm{C}=\mathrm{C}$ (stretching), at $\mathrm{v} 1500-1600 \mathrm{~cm}^{-1}$. infrared spectrum of compound (1), in which $\mathrm{v}-\mathrm{C}=\mathrm{N}$ absorption appear at $1608.63 \mathrm{~cm}^{-1}$ and $\mathrm{v}-\mathrm{OH}$ at $3440-3485 \mathrm{~cm}^{-1}$, as broad band compared with the absorption of $\mathrm{v}-\mathrm{C}=\mathrm{N}$ at $1600.92 \mathrm{~cm}^{-1}$ for compound 9 , which are affected by both $(\mathrm{X})$ and $(\mathrm{Y})$ substituents. The substituent of electron withdrawing group $\left(-\mathrm{NO}_{2}\right)$ para to $-\mathrm{C}=\mathrm{N}$, shift the absorption of $\mathrm{v}-\mathrm{C}=\mathrm{N}$ to higher frequency as a result of decrease in electron density on $\mathrm{C}=\mathrm{N}$ bond, induced by electron withdrawing $\mathrm{NO}_{2}$ group.

IR spectrum of compound (9), shows ( $\mathrm{C}=\mathrm{C}-\mathrm{H})$, for aromatic ring, stretching frequency, abdsorbed at 3039.81 $\mathrm{cm}^{-1}$, v $2964.59 \mathrm{~cm}^{-1}$, and $\mathrm{CH}_{3}$ stretching vibration appear at $\mathrm{v} 2864.59 \mathrm{~cm}^{-1}$. These results are in agreement with published results [13] [14].

The ${ }^{1} \mathrm{H}$ NMR spectra of imines having $\mathrm{CH}_{3}$-substituents (imines, 1 - 9) in pyridine ring, the $\mathrm{CH}_{3}$ and $=\mathrm{C}-\mathrm{H}$ groups of this imines appear as a single peak at $\delta(2.37-2.60) \mathrm{ppm}$ for $\mathrm{CH}_{3}$ groups, and at $\delta(9.01-9.43) \mathrm{ppm}$ as a single peak for $\mathrm{C}-\mathrm{H}$ protons. These results indicate that only one diasterioisomeris present in the solution for these imines.

The ${ }^{1} \mathrm{H}-\mathrm{NMR}$ spectra of imines (7) has been chosen as a model in order to simplify the NMR spectra. In $\mathrm{CDCl}_{3}$ solution, the $\mathrm{Ar}-\mathrm{CH}_{3}$ group resonates at $\delta 2.59 \mathrm{ppm}$ (single peak) and -OH group resonates at $\delta 13.59$ ppm (single peak). The $\mathrm{H}-\mathrm{C}=$ Proton resonate at $\delta 9.43 \mathrm{ppm}$ (single peak). The aromatic protons appear as (ABA'B') pattern. The pyridine proton, $\mathrm{H} 6$ of imine (7) resonate at $\delta 7.67 \mathrm{ppm}$ (doublet of doublet) at low field, and so the $\mathrm{H} 3$ and $\mathrm{H} 5$, and due to the absorption of pyridine protons and aromatic ring protons absorb in the same region, a complicated and observed as an overlap spectra.

The ${ }^{13} \mathrm{C}$-NMR spectra of imine (7) has been chosen model in order to simplify the ${ }^{13} \mathrm{C}$-NMR spectra. The quaternary carbon in pyridine and aromatic rings and imine group $\mathrm{C}=\mathrm{N}$, are readily identified since they are less intense compared with other signals as a result of long relaxation times of the quaternary carbons [15] [16]. The ${ }^{13} \mathrm{C}$ spectrum (in $\mathrm{CDCl}_{3}$ ), shows signals at $\delta 164.15 \mathrm{ppm}$ and single peak at $\delta 24.38 \mathrm{ppm}$ for pyridine $-\mathrm{CH}_{3}$ group. The C-2' (attached to $\mathrm{OH}$ group) show signal at $\delta 161.62 \mathrm{ppm}$. The total numbers of carbons in both rings and $\mathrm{C}=\mathrm{N}$ group are 12 carbons, this is demonstrated in the experimental part.

Further evidence comes from imine spectrum of compound (13). The proton NMR spectrum shows signal at $\delta$ $9.08 \mathrm{ppm}$ (single peak) for ${ }^{1} \mathrm{H}-\mathrm{C}=\mathrm{N}$ proton, and another signal at $\delta 8.42 \mathrm{ppm}$ assigned for $\mathrm{C}_{6}-\mathrm{H}$. The ${ }^{1} \mathrm{H}-\mathrm{NMR}$ signals $\mathrm{C}_{3}-\mathrm{H}, \mathrm{C}_{4}-\mathrm{H}$ (on pyridine ring) and aromatic protons signals shown at $\delta 7.26-7.84 \mathrm{ppm}$ together. But the case will be different by studying the ${ }^{13} \mathrm{C}$-NMR of imine (13). The numbers of ${ }^{13} \mathrm{C}$ are 10 carbons. The quaternary carbon is less intense compared with other carbon signals. The assignments of the chemical shifts of the backbone carbons are based either on spin-lattice relaxation or on the study of substituent effects in benzene derivatives [17] [18].

The ${ }^{13} \mathrm{C}$ chemical shifts of imines are listed in the experimental part. It is worth noting that the carbon -13 chemical shifts for isomethine group (imines) $(\mathrm{HC}=\mathrm{N})$ carbons are affected by both $(\mathrm{X})$ and $(\mathrm{Y})$ substituent's on aromatic and pyridine rings respectively. When (X)- $\mathrm{NO}_{2}$ group substituted at $\mathrm{C}-4$, the $\mathrm{C}=\mathrm{N}$, singleresonance 
Table 3. $\delta{ }^{1} \mathrm{H}-\mathrm{CH}=\mathrm{N}$ and $\delta{ }^{13} \mathrm{C}=\mathrm{N}$ for Schiff bases $(1-13)$.

\begin{tabular}{|c|c|c|c|c|c|}
\hline Complex No. & $\delta{ }^{13} \mathrm{C}=\mathrm{N}(\mathrm{ppm})$ & $\delta{ }^{1} \mathrm{H}-\mathrm{CH}=\mathrm{N}(\mathrm{ppm})$ & Complex No. & $\delta^{13} \mathrm{C}=\mathrm{N}(\mathrm{ppm})$ & $\delta^{1} \mathrm{H}-\mathrm{CH}=\mathrm{N}(\mathrm{ppm})$ \\
\hline 1 & 163.50 & 9.44 & 8 & 159.39 & 9.26 \\
\hline 2 & 164.11 & 9.15 & 9 & 161.13 & 9.11 \\
\hline 3 & 146.24 & 9.42 & 10 & 163.46 & 9.12 \\
\hline 4 & 159.25 & 9.25 & 11 & 164.97 & 9.41 \\
\hline 5 & 161.02 & 9.01 & 12 & 160.52 & 9.26 \\
\hline 6 & 164.65 & 9.15 & 13 & 162.00 & 9.08 \\
\hline 7 & 164.15 & 9.43 & & & \\
\hline
\end{tabular}

appear at $\delta 159.39 \mathrm{ppm}$, the more electron withdrawing group, the more shielding effect. The substitution at pyridine ring shows less effect on $\delta \mathrm{C}=\mathrm{N}$ absorption (Table 3).

\section{Conclusion}

The new pyridine imines derivatives have been characterized by elemental analysis, UV, IR, ${ }^{1} \mathrm{H}$, and ${ }^{13} \mathrm{C}-\mathrm{NMR}$ spectroscopy. Interestingly, the carbon- 13 chemical shifts for azomethine group (imines) $(\mathrm{CH}=\mathrm{N})$ carbons which are affected by both $(\mathrm{X})$ and $(\mathrm{Y})$ substituents. The stereochemistry of the imines was determined through their NMR spectral data. The imines were found to exist in solution as only a single E-isomer at ambient temperature.

\section{Acknowledgements}

The authors would like to thank the Research Center, College of Science, Princess Nora University and King Abdulaziz city for Science and Technology for the financial support to this Research Project (AT-17-171).

\section{References}

[1] Brodowska, K. and Lodyga-Chruścińska, E. (2014) Schiff Bases-Interesting Range of Applications in Various Fields of Science. Chemik, 68, 129-134.

[2] Kundariyal, D.S., Patel, P.K. and Bheshdadia, B.M. (2014) Synthesis, Characterization and Biological Activity of 4-Thiazolidinone Derivatives Containing 1H-Pyrazolo[3,4-b]Pyridine Nucleus. Der Chemica Sinica, 5, 138-143. http://pelagiaresearchlibrary.com/der-chemica-sinica/vol5-iss1/DCS-2014-5-1-138-143.pdf

[3] Kumar, P.P. and Rani, B.L. (2011) Synthesis and Characterization of New Schiff Bases Containing Pyridine Moiety and Their Derivatives as Antioxidant Agents. International Journal of ChemTech Research, 3, 155-160.

[4] Bhatia, M.S., Mulani, A.K., Chaudhary, P.B., Ingale, K.B. and Bhatia, N.M. (2009) Synthesis and QSAR Analysis of 5-Substituted (Aryl Methylene) Pyridine-2-Amine Derivatives as Potential Antibacterials. International Journal of Drug Discovery, 1, 1-9. http://oaji.net/articles/36-1394004826.pdf

[5] Amr, A.G., Mohamed, A.M., Mohamed, S.F., Abdel-Hafez, N.A. and El-Fotooh G. Hammam, A. (2006) Anticancer Activities of Some Newly Synthesized Pyridine, Pyrane and Pyrimidine Derivatives. Bioorganic \& Medicinal Chemistry, 14, 5481-5488. http://www.sciencedirect.com/science/article/pii/S0968089606003452 http://dx.doi.org/10.1016/j.bmc.2006.04.045

[6] Jansen, B.A.J., van der Zwan, J., den Dulk, H., Brouwer, J. and Reedijk, J. (2001) Dinuclear Alkyl Diamine Platinum Antitumor Compounds: A Structure-Activity Relationship Study. Journal of Medicinal Chemistry, 44, 245-249. http://pubs.acs.org/doi/pdf/10.1021/jm0010163

[7] Hisashi, S., Takao, I., Tetsuya, I., Yuki, K., Hideki, Y. and Itsuo, U. (2000) 4-Aminoquinolines: Novel Nociceptin Antagonists with Analgesic Activity. Journal of Medicinal Chemistry, 43, 4667-4677. http://dx.doi.org/10.1021/jm0002073

[8] Věra, K., Martin, S., Waisser, W.K., Milan, P. and Jarmila, K. (1999) New Pyridine Derivatives as Potential Antimicrobial Agents. IlFarmaco, 54, 666-672. http://dx.doi.org/10.1016/S0014-827X(99)00078-6

[9] Curtin, D.Y. and Hausser, J.W. (1961) Effects of Structural Changes on the Interconversion of Stereoisomeric Imines, Isoelectronic Models for Vinyl Anions. Journal of the American Chemical Society, 83, 3474-3481. 
http://dx.doi.org/10.1021/ja01477a029

[10] Audoye, P., Coumes, R.-C., Gaset, A. and Gorrichon, J.-P. (1982) Etude structural d'aldiminesderivées des furanne-, thiophène- et N-méthylpyrrole carboxaldéhydes-2,1-N-hétéroarylidene anilines. Canadian Journal of Chemistry, 60, 1148-1154. http://www.nrcresearchpress.com/doi/pdf/10.1139/v82-170

[11] Al-Showiman, S.S., Al-Shalaan, A.M. and Al-Najjar, I.M. (1987) ${ }^{1} \mathrm{H}$ and ${ }^{13} \mathrm{C}$ NMR Studies of Some N-Alkylimines Derived from Thiophenes. The Arab Gulf Journal of Scientific Research, A5, 359-375.

[12] Al-Showiman, S.S., Al-Najjar, I.M. and Al-Shalaan, A.M. (1987) ${ }^{1} \mathrm{H}$ and ${ }^{13} \mathrm{C}$ NMR Study of Some N-Alkylimines Derived from Furfural and 2-Acetyl Furan. Spectrochimica Acta Part A: Molecular Spectroscopy, 43, 1055-1058. http://www.sciencedirect.com/science/article/pii/0584853987801782

[13] Al-Douh, M.H., Al-Fatlawy, A.A. and Abid, O.H. (2004) Synthesis and Characterization of Some 2-(N-BenzoylN-Pyrid-2-yl Aminobenzyl)Aminobarbituric Acids via N-Benzylidene Pyridine-2-Amines. Journal of Natural and Applied Sciences, 8, 181-194. http://www.academia.edu/5199250/

[14] Dal, H., Süzen, Y. and Sahin, E. (2007) Synthesis, Spectral Studies of Salicylidene-Pyridines: Crystal and Molecular Structure of 2-[(1E)-2-aza-2-(5-Methyl(2-Pyridyl)Ethenyl)]-4-Bromobenzen-1-ol. Spectrochimica Acta Part A: Molecular Spectroscopy, 67, 808-814. http://www.sciencedirect.com/science/article/pii/S1386142506005130

[15] Al-Najjar, I.M. and Amin, H.B. (1987) The Carbon-13 Chemical Shifts and the Analysis of the Relaxation Times T1 and Long Range ${ }^{13} \mathrm{C}-{ }^{1} \mathrm{H}$ Coupling Constants of Quinoline and of 1-(X-Quinolyl) Ethyl Acetate Derivatives. Spectrochimica Acta Part A: Molecular Spectroscopy, 43, 1307-1315. http://dx.doi.org/10.1016/S0584-8539(87)80002-8

[16] Al-Showiman, S.S., Al-Najjar, I.M. and Amin, H.B. (1982) ${ }^{13}$ C NMR Spectra of Benzo[b]Thiophene and 1-(X-Benzo[b]Thienyl Acetate Derivatives. Organic Magnetic Resonance, 20, 105-112. http://onlinelibrary.wiley.com/doi/10.1002/mrc.1270200208/

[17] Ewing, D.F. (1979) ${ }^{13}$ C Substituent Effects in Monosubstituted Benzenes. Organic Magnetic Resonance, 12, $499-524$. http://dx.doi.org/10.1002/mrc.1270120902

[18] Arrosmith, J.E., Cook, M.J., Cook, D.J. and Hardsone, D.J. (1978) Long-Range Substituent Induced Chemical Shifts in ${ }^{13} \mathrm{C}$ NMR Spectra of n-Benzylidene Benzyl Amines. Organic Magnetic Resonance, 11, 160-161. http://dx.doi.org/10.1002/mrc.1270110314 